Cord 2007, 23 (2)

\title{
Recovery pattern of cyclone-affected coconut palms in littoral sandy soils of Orissa-Part II
}

\author{
G.C. Acharya ${ }^{1}$, D.P. Ray ${ }^{2}$ and D.K. Dash ${ }^{3}$
}

\begin{abstract}
The experiment to study the recovery pattern of cyclone affected palms cv. Sakhigopal Local was carried out in an ongoing fertilizer trial with three levels each of $\mathrm{N}(500,1000$ and $1500 \mathrm{~g} \mathrm{~N} / \mathrm{palm} / \mathrm{year})$, $\mathrm{P}$ (250, 500 and $750 \mathrm{~g} \mathrm{P}_{2} \mathrm{O}_{5} /$ palm/year) and $\mathrm{K}\left(750,1250\right.$ and $1750 \mathrm{~g}$ of $\mathrm{K}_{2} \mathrm{O} / \mathrm{palm} / \mathrm{year}$ ) at Coconut Research Station under Orissa University of Agriculture and Technology. The study indicated that the manuring practices comprising higher doses of $\mathrm{N}, \mathrm{P}$ and $\mathrm{K}$ were most effective, nitrogen in particular in bringing out a gradual improvement in the reproductive characters of the coconut palms affected by the super cyclone, 1999. Enhanced nitrogen application $(1000 \mathrm{~g} / \mathrm{palm} / \mathrm{year})$ induced production of more number of inflorescences, more of female flowers and increased yield per palm during initial years of damage irrespective of the degree of damage suffered by the adult palms in the littoral sandy soils of Orissa. The nut yield per palm per year exhibited significant increase at $\mathrm{N}$ levels of 500 to $1000 \mathrm{~g}$ per palm per year during 2001-02 to 2003-04 under damage category I. The importance of this level of nitrogen was marked during 2000-01 to 2002-03 in damage category II and during 2000-01 to 2001-02 in damage category III. The $1500 \mathrm{~g}$ nitrogen per palm per year did not show any significant change over $1000 \mathrm{~g}$ as regards to the nut yield per palm.
\end{abstract}

Key words: Coconut, Sakhigopal Local, Super-cyclone, Littoral, Recovery.

${ }^{1}$ CPCRI, Research Centre, Mohitnagar, Jalpaiguri, West Bengal-735 101, India.

${ }^{2}$ Dean, Registrar and ex-Head, Orissa Univ. of Agril \& Tech. Bhubaneswar.

${ }^{3}$ Associate Professor, AICRP (Palms), Orissa Univ. of Agril \& Tech. Bhubaneswar. 


\section{Introduction}

In Orissa, the area under coconut in 20042005 is estimated at 50,800 ha with an annual production of 274.8 million nuts. One of the reasons for the low productivity of around 5,400 nuts per ha is the occurrence of frequent cyclones arresting the coconut production temporarily for 2-3 years. In the past 100 years, the state had experienced 79 storms but the cyclone happened on $29^{\text {th }}$ November 1999 was, perhaps, the worst and an estimated 23,479 ha of coconut plantations in 13 districts were damaged. The cyclone damage to the palms and the dynamics of the recovery following the damage have received focused attention of research. Despite the knowledge that the influence of a cyclone on crop production lasts for many years, post-cyclone recovery dynamics has received little attention. Keeping this fact in view, an experiment was designed to study the recovery pattern in respect of reproductive characters of the coconut palm in three different damage categories under different fertilizer combinations.

\section{Materials and methods}

The experiment to study the recovery pattern of cyclone-affected palms was conducted in the Coconut Research Station under Orissa University of Agriculture and Technology. Palms subjected to the study belonged to the variety "Sakhigopal Local", aged 27 years, and planted at a spacing of $7.5 \mathrm{~m} \times 7.5 \mathrm{~m}$ with a population density of 175 palms per hectare. The palms were drip irrigated uniformly @32 litres/palm/day through drippers from October onwards till the onset of monsoon in June. The experiment on the cyclone recovery study was carried out in an ongoing fertilizer trial with three levels each of $\mathrm{N}$ (500, 1000 and $1500 \mathrm{~g} \mathrm{~N} /$ palm/year), $\mathrm{P}$ (250, 500 and $750 \mathrm{~g} \mathrm{P}_{2} \mathrm{O}_{5} /$ palm/ year) and $\mathrm{K}(750,1250$ and $1750 \mathrm{~g}$ of $\mathrm{K}_{2} \mathrm{O} / \mathrm{palm} / \mathrm{year}$ ). The palms received the required nutrients through urea, single super phosphate and muriate of potash for nitrogen, phosphorus and potassium, respectively. One third of the total dose was applied during the month of May before the onset of Southwest monsoon and the balance during September-October. The fertilizers were applied around the base of the palm after removing all the weeds, within a radius of $1.0-1.5 \mathrm{~m}$. The fertilizers were broadcasted over the circle weeded area and incorporated to a depth of 5-8 $\mathrm{cm}$ with the use of a suitable digging tool. This study was laid out following a $3^{3}$ Confounding Design with two replications and two palms per replication.

Types of damage studied:-

\begin{tabular}{|ll|}
\hline Damage category & \multicolumn{1}{c|}{ Nature of damage } \\
\hline Damage category I & $\begin{array}{l}\text { Few leaves of lower } \\
\text { whorl, majority of the } \\
\text { leaves in the middle and } \\
\text { top whorl were } \\
\text { completely broken/ } \\
\text { twisted, giving } \\
\text { appearance of a a } \\
\text { beheaded to palm, } \\
\text { suspecting damage to } \\
\text { the cabbage of the palm. }\end{array}$ \\
\hline Damage category II & $\begin{array}{l}\text { Majority of the leaves in } \\
\text { the middle whorl and } \\
\text { young leaves of top } \\
\text { whorl were broken/ } \\
\text { damaged/ twisted giving } \\
\text { an appearance of crown } \\
\text { twisting. }\end{array}$ \\
\hline Damage category III & $\begin{array}{l}\text { Majority of the leaves } \\
\text { were affected in the } \\
\text { windward direction. } \\
\text { Only the top young } \\
\text { leaves were damaged/ } \\
\text { broken. }\end{array}$ \\
\hline
\end{tabular}

\section{Results:}

\section{Recovery of the palms with respect to the production of inflorescences}
1.1. Recovery of the palms under damage category I:


The recovery of the palms in respect of the rate of inflorescences production has been presented in Table 3 . The rate of production during first eight months of damage was almost insignificant when compared to the rate of production of the same as in a normal year before the event (8.56). After 1999-00, there was a steady increase in the number of inflorescences reaching 7.44 at the end of the experimental period.

The palms receiving varying doses of nitrogen exhibited significant effects on the production of inflorescences per palm per year during 2000-01 to 2002-03. The rate of production has significantly increased from 2.58 to $2.86,5.36$ to 5.69 and 6.69 to 7.11 with the increase in the level of nitrogen from $500 \mathrm{~g}$ per palm per year to $1000 \mathrm{~g}$ per palm per year during 2000-01, 2001-02, and 2002-03, respectively. However, further increase in the level of nitrogen to $1500 \mathrm{~g}$ per palm per year did not bring any significant changes in this character during the above periods. The palms receiving different levels of phosphorus and potassium did not show significant changes on the rate of production of inflorescences during the post-cyclonic period (1999-00 to 2003-04).

\subsection{Recovery of the palms under damage category II:}

The data recorded on production of inflorescences per palm per year was statistically analyzed and the summarized data have been presented in Table 4.

The production of inflorescences per palm per year, which was 8.97 before the cyclone, was reduced to 1.98 during first 8 months after the damage. Thereafter, gradual improvement was noticed in this character up to 2003-04, though more marked between 1999-00 \& 2000-01 and 2000-01 \& 2001-02. Varying levels of nitrogen influenced the rate of inflorescences production significantly during 1999-00, 2000-01 and 2001-02. The increment in the dose of nitrogen from $500 \mathrm{~g}$ to $1000 \mathrm{~g}$ per palm per year resulted in corresponding significant increase in the inflorescences production. Application of 1000 $\mathrm{g}$ nitrogen per palm per year resulted in the production of 2.06, 5.89 and 8.08 inflorescences per palm during 1999-00, 2000-01, and 200102 , respectively, as against $1.81,5.53$, and 7.56 with the application of $500 \mathrm{~g}$ during these years. Higher level at $1500 \mathrm{~g}$ per palm per year was not superior to the level of $1000 \mathrm{~g}$ per palm. Towards later part of the study i.e., during 200203 and 2003-04, the difference among the various levels of nitrogen nutrition was nonsignificant in terms of this character.

The effect of different doses of phosphorus and potassium nutrition was found to be nonsignificant on this character during the reporting period.

\subsection{Recovery of the palms under damage category III:}

The data pertaining to the production of inflorescences per palm per year were statistically analyzed and the analyzed data have been presented in Table 5. The data in the summarized table exhibited consistent improvement in the production of inflorescences per palm from 1999-00 to 2003-04 (2.68 to 8.86). It has almost reached normal at the end of the study period i.e., after 2-3 years of damage. The production of inflorescences per palm per year during the post cyclone damage was maximum at $\mathrm{N}_{1000}$ except in 2001-02 when $\mathrm{N}_{1500}$ had better effect.

Table 1. Mechanical analysis of the soil*

\begin{tabular}{|l|c|c|}
\hline \multirow{2}{*}{ Components } & \multicolumn{2}{|c|}{ Soil depth $(\mathrm{cm})$} \\
\cline { 2 - 3 } & $0-25$ & $25-50$ \\
\hline Sand (\%) & 89.4 & 89.3 \\
\hline Silt (\%) & 3.4 & 3.6 \\
\hline Clay (\%) & 7.2 & 7.1 \\
\hline
\end{tabular}


* International Pipette Method (Piper, 1950).

Table 2. Chemical analysis of the soil

\begin{tabular}{|l|c|c|l|}
\hline \multirow{2}{*}{ Components } & \multicolumn{2}{|c|}{ Soil depth $(\mathrm{cm})$} & Methods \\
\cline { 2 - 4 } & $0-25$ & $25-50$ & \\
\hline Available $\mathrm{N}(\mathrm{kg} / \mathrm{ha})$ & 118.7 & 60.8 & $\begin{array}{l}\text { Alkaline Permanganate method (Subbiah and Asija, } \\
\text { 1956). }\end{array}$ \\
\hline Available $\mathrm{P}_{2} \mathrm{O}_{5}(\mathrm{~kg} / \mathrm{ha})$ & 178.2 & 124.1 & $\begin{array}{l}\text { Bray's extractant spectrophotometric method } \\
\text { (Jackson, 1973). }\end{array}$ \\
\hline Available $\mathrm{K}_{2} \mathrm{O}(\mathrm{kg} / \mathrm{ha})$ & 145.4 & 186.2 & $\begin{array}{l}\text { Ammonium acetate extractant flame photometric } \\
\text { method (Jackson, 1973). }\end{array}$ \\
\hline Organic carbon $(\%)$ & 0.19 & 0.08 & Walkley and Black (Jackson, 1973). \\
\hline $\mathrm{p}^{\mathrm{H}}(1: 2$ soil to water ratio) & 5.48 & 6.30 & Potentiometric method (Jackson, 1973). \\
\hline $\begin{array}{l}\text { Electrical conductivity (dSm } \\
(1: 2 \text { soil to water ratio) }\end{array}$ & 0.027 & 0.095 & Conductometric method (Jackson, 1973). \\
\hline
\end{tabular}

Table 3. Rate of inflorescence production (nos.) in successive years for damage category I

\begin{tabular}{|c|c|c|c|c|c|c|}
\hline \multirow[t]{2}{*}{ Treatment } & Pre- & Cyclonic & \multicolumn{4}{|c|}{ Post-cyclonic period } \\
\hline & $\begin{array}{l}\text { 1998-99 } \\
\text { (Nov.-Oct.) }\end{array}$ & $\begin{array}{l}\text { 1999-00 } \\
\text { (Nov.-June) }\end{array}$ & $\begin{array}{l}2000-01 \\
\text { (July-June) }\end{array}$ & $\begin{array}{l}2001-02 \\
\text { (July-June) }\end{array}$ & $\begin{array}{l}\text { 2002-03 } \\
\text { (July-June) }\end{array}$ & $\begin{array}{l}\text { 2003-04 } \\
\text { (July-June) }\end{array}$ \\
\hline \multicolumn{7}{|c|}{ Nitrogen ( $g /$ plant) } \\
\hline $\mathrm{N}_{500}$ & 8.47 & In-sig. & 2.58 & 5.36 & 6.69 & 7.31 \\
\hline $\mathrm{N}_{1000}$ & 8.64 & In-sig. & 2.86 & 5.69 & 7.11 & 7.50 \\
\hline $\mathrm{N}_{1500}$ & 8.58 & In-sig. & 3.06 & 5.67 & 7.06 & 7.50 \\
\hline $\operatorname{SEm}( \pm)$ & 0.105 & --- & 0.078 & 0.096 & 0.109 & 0.072 \\
\hline C.D. (0.05) & NS & --- & 0.23 & 0.28 & 0.32 & NS \\
\hline \multicolumn{7}{|c|}{ Phosphorus ( $\mathrm{g} \mathrm{P}_{2} \mathrm{O}_{5} /$ plant $)$} \\
\hline $\mathrm{P}_{250}$ & 8.67 & In-sig. & 2.83 & 5.53 & 6.97 & 7.50 \\
\hline $\mathrm{P}_{500}$ & 8.53 & In-sig. & 2.89 & 5.64 & 6.97 & 7.42 \\
\hline$P_{750}$ & 8.50 & In-sig. & 2.78 & 5.56 & 6.92 & 7.39 \\
\hline $\operatorname{SEm}( \pm)$ & 0.105 & --- & 0.078 & 0.096 & 0.109 & 0.072 \\
\hline C.D. (0.05) & NS & --- & NS & NS & NS & NS \\
\hline \multicolumn{7}{|c|}{ Potassium ( $\mathrm{g} \mathrm{K} \mathrm{K}_{2} \mathrm{O} /$ plant $)$} \\
\hline $\mathrm{K}_{750}$ & 8.61 & In-sig. & 2.83 & 5.58 & 7.00 & 7.53 \\
\hline $\mathrm{K}_{1250}$ & 8.53 & In-sig. & 2.89 & 5.67 & 7.06 & 7.44 \\
\hline $\mathrm{K}_{1750}$ & 8.56 & In-sig. & 2.78 & 5.47 & 6.81 & 7.33 \\
\hline $\operatorname{SEm}( \pm)$ & 0.105 & --- & 0.078 & 0.096 & 0.109 & 0.072 \\
\hline C.D. (0.05) & NS & --- & NS & NS & NS & NS \\
\hline Mean & 8.56 & In-sig. & 2.83 & 5.57 & 6.95 & 7.44 \\
\hline
\end{tabular}

Table 4. Rate of inflorescence production (nos.) in successive years for damage category II

\begin{tabular}{|c|c|c|c|c|c|c|}
\hline \multirow[t]{2}{*}{ Treatment } & Pre- & Cyclonic & \multicolumn{4}{|c|}{ Post-cyclonic period } \\
\hline & $\begin{array}{l}1998-99 \\
\text { (Nov.-Oct.) }\end{array}$ & $\begin{array}{l}\text { 1999-00 } \\
\text { (Nov.-June) }\end{array}$ & $\begin{array}{l}2000-01 \\
\text { (July-June) }\end{array}$ & $\begin{array}{l}\text { 2001-02 } \\
\text { (July-June) }\end{array}$ & $\begin{array}{l}\text { 2002-03 } \\
\text { (July-June) }\end{array}$ & $\begin{array}{l}\text { 2003-04 } \\
\text { (July-June) }\end{array}$ \\
\hline \multicolumn{7}{|c|}{ Nitrogen (g/plant) } \\
\hline $\mathrm{N}_{500}$ & 8.97 & 1.81 & 5.53 & 7.56 & 8.53 & 8.75 \\
\hline $\mathrm{N}_{1000}$ & 9.00 & 2.06 & 5.89 & 8.08 & 8.58 & 8.92 \\
\hline
\end{tabular}




\begin{tabular}{|c|c|c|c|c|c|c|}
\hline $\mathrm{N}_{1500}$ & 8.94 & 2.08 & 5.83 & 8.00 & 8.56 & 8.81 \\
\hline SEm $( \pm)$ & 0.115 & 0.066 & 0.096 & 0.128 & 0.123 & 0.094 \\
\hline C.D. (0.05) & NS & 0.19 & 0.28 & 0.38 & NS & NS \\
\hline \multicolumn{7}{|c|}{ Phosphorus ( $\mathrm{g} \mathrm{P}_{2} \mathrm{O}_{5} /$ plant $)$} \\
\hline $\mathrm{P}_{250}$ & 9.03 & 2.03 & 5.75 & 7.86 & 8.50 & 8.81 \\
\hline $\mathrm{P}_{500}$ & 9.00 & 2.03 & 5.89 & 7.86 & 8.72 & 8.89 \\
\hline $\mathrm{P}_{750}$ & 8.89 & 1.89 & 5.61 & 7.92 & 8.44 & 8.78 \\
\hline SEm $( \pm)$ & 0.115 & 0.066 & 0.096 & 0.128 & 0.123 & 0.094 \\
\hline C.D. (0.05) & NS & NS & NS & NS & NS & NS \\
\hline \multicolumn{7}{|c|}{ Potassium ( $\mathrm{g} \mathrm{K}_{2} \mathrm{O} /$ plant) } \\
\hline $\mathrm{K}_{750}$ & 9.03 & 2.06 & 5.83 & 7.89 & 8.56 & 8.94 \\
\hline $\mathrm{K}_{1250}$ & 8.92 & 1.97 & 5.72 & 7.89 & 8.61 & 8.72 \\
\hline $\mathrm{K}_{1750}$ & 8.97 & 1.92 & 5.69 & 7.86 & 8.50 & 8.81 \\
\hline $\operatorname{SEm}( \pm)$ & 0.115 & 0.066 & 0.096 & 0.128 & 0.123 & 0.094 \\
\hline C.D. $(0.05)$ & NS & NS & NS & NS & NS & NS \\
\hline Mean & 8.97 & 1.98 & 5.75 & 7.88 & 8.56 & 8.82 \\
\hline
\end{tabular}

Table 5. Rate of inflorescence production (nos.) in successive years for damage category III

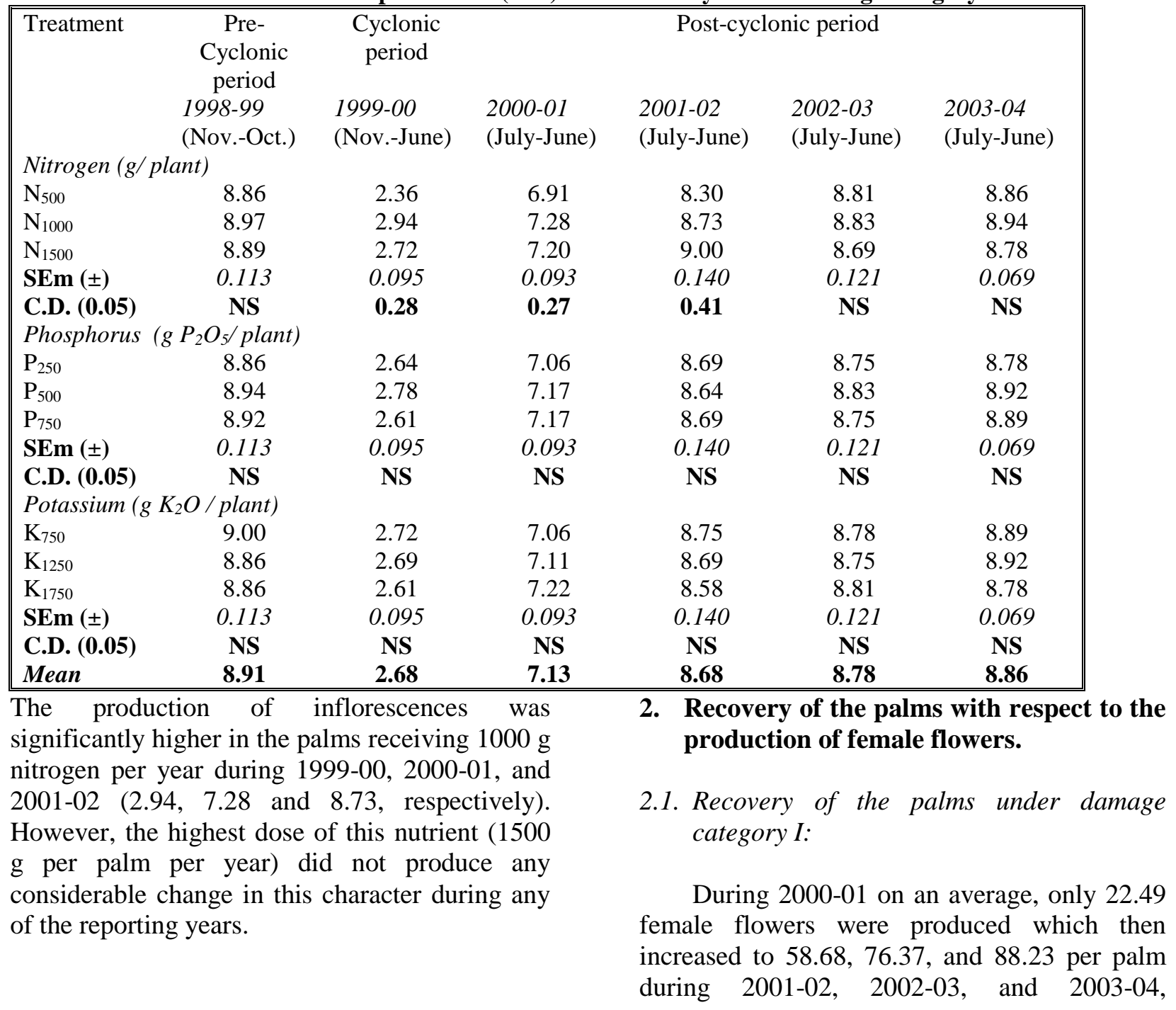


respectively. It was also observed that even after about 5 years of damage the female flower production did not reach the normal figure that is 137.04, recorded during the pre-cyclonic period (Fig 1).

Application of nitrogen enhanced the number of female flower production conspicuously during every year of the investigation (2000-01 to 2003-04). The increasing dose of nitrogen up to $1000 \mathrm{~g}$ per palm per year resulted in corresponding significant increase in this character. Further increase in the dose to $1500 \mathrm{~g}$, however, did not induce any significant improvement in the production of female flowers per palm per year. A critical analysis on the effect of varying levels of nitrogen on the female flower production per palm (Table 6 and Fig 1) revealed that the number of female flower production per palm has significantly increased to $23.78,60.89,77.47$, and 89.19 at $\mathrm{N}_{1000}$ from $19.42,54.78,75.03$, and 85.25 at $\mathrm{N}_{500}$ during 2000-01, 2001-02, 2002-03, and 2003-04, respectively. The magnitude of variations as observed due to the different levels of phosphorus and potassium was not significant with respect to female flower production per palm in any of the years under study.

\subsection{Recovery of the palms under damage category II:}

The female flower production per palm gradually increased in the succeeding years to $60.79,103.61,123.67$, and 130.02 during 200001, 2001-02, 2002-03, and 2003-04, respectively. The degree of increment was more pronounced between 1999-00 \& 2000-01 and 2000-01 \& 2001-02. The number of female flowers per palm was augmented significantly by the application of nitrogen. Of the various nitrogen levels applied, $1000 \mathrm{~g}$ per palm per year proved to be most beneficial as its administration produced significantly more number of female flowers i.e., $18.92,63.56,105.86,124.75$, and 130.75 than with the application of $500 \mathrm{~g}$ nitrogen per palm during 1999-00, 2000-01, 2001-02, 2002-03, and 2003-04, respectively. Although, during 2002-03 and 2003-04, application of $1500 \mathrm{~g}$ nitrogen per palm per year showed better effect but only at par with the results obtained at $\mathrm{N}_{1000}$ in terms of this character.

\subsection{Recovery of the palms under damage category III:}

On an average, the female flower production per palm was 137.98 before the cyclone, which then decreased by about 81 per cent (25.47) as noted in 1999-00. Subsequently, the female flower production increased gradually reaching almost normality during 2002-03 and 2003-04. The levels of nitrogen fertilization were found to produce marked effect on the female flower production per palm. The increasing nitrogen fertilization showed corresponding significant increase in the number of female flowers per palm up to $\mathrm{N}_{1000}$ after which the variation was non-significant. During 1999-00, the number of female flower production per palm at $\mathrm{N}_{500}$ was 24.47 , which increased significantly to 26.25 at the extra 500 $\mathrm{g}$ nitrogen fertilization (Table 8 and Fig 1). The corresponding figures for 2000-01, 2001-02, 2002-03 and 2003-04 were 92.97, 127.50, 129.97 , and 133.53 at $\mathrm{N}_{500}$ which then increased to $100.36,138.25,137.92$ and 137.42, respectively, at $\mathrm{N}_{1000}$.

\section{Recovery of the palms with respect to the annual nut yield per palm}

\subsection{Recovery of the palms under damage category I:}

The statistically analyzed data pertaining to the annual nut yield per palm has been summarized and presented in Table 9 and Fig 2. It was observed that the palms that used to produce about 25.84 nuts in a normal year took about 2-3 years to restart the bearing under this category of cyclonic damage. On an average, the nut production was started regularly in 2001-02 with 4.19 nuts per palm and went on increasing to 13.88 nuts per palm at the end of the experimental period. Rates of the nitrogen fertilization produced well-marked variations in the annual nut yield per palm in all the years of the reporting period after the cyclone. The annual nut yield was the minimum $(3.36,7.75$ 
and 12.69 during 2001-02, 2002-03, and 200304 , respectively) when the palms were supplied with $500 \mathrm{~g}$ nitrogen per palm per year. With the administration of $1000 \mathrm{~g}$ nitrogen per palm per year, the nut yield was significantly higher than the former by 32.1 per cent in 2001-02, 21.5 per cent in 2002-03 and 14.9 per cent in 2003-04. However, no significant effect on nut yield was observed at the highest dose of nitrogen (1500 g per palm per year) in any of the years covered. The effect of different levels of phosphorus and potassium on this character was not statistically significant.

\subsection{Recovery of the palms under damage category II:}

The data on the nut yield per palm per year were analyzed and presented in Table 10. The perusal of the data indicated that the nut yield per palm during 1998-99 (supposed to be a normal year) was 26.56, which became almost insignificant during 1999-00, i.e., during the first eight months after cyclone. During the later years the yield per palm recorded was 2.46, 10.92, 17.44 , and 22.61 during 2000-01, 2001-02, 200203 , and 2003-04, respectively.

The increasing level of nitrogen up to 1000 g per palm per year consistently increased the nut yield per palm during 2000-01 to 2002-03 while the highest dose of nitrogen (1500 g per palm per year) did not indicate any significant change as compared to $1000 \mathrm{~g}$ nitrogen per palm per year. An increase in the level of nitrogen from $500 \mathrm{~g}$ to $1000 \mathrm{~g}$ per palm per year augmented the nut yield significantly i.e., from 2.22 to $2.53,9.47$ to 11.58 , and from 16.31 to 18.25 during $2000-01$, 2001-02, and 2002-03, respectively. The nut yield in the palms fertilized with 1250 and 1750 g potassium per palm per year was significantly higher than that in the palms fertilized with 750 g potassium per palm during 2000-01 and 200102. Application of potassium at the rate of 1250 g per palm per year produced maximum number of nuts i.e., 2.56 and 11.17 per palm during 2000-01 and 2001-02, respectively, when compared to those fertilized with $750 \mathrm{~g}$ potassium. Furthermore, the highest dose of potassium (1750 g per palm per year) applied in this study, however, stood at par with the $1250 \mathrm{~g}$ per palm per year level during 2000-01 and 2001-02. The same trend continued to exist in 2002-03 and 2003-04 but there was no marked variation among all the three levels of potassium fertilization tried in this experiment.

\subsection{Recovery of the palms under damage category III:}

The data in the Table 11 revealed considerable decrease in the nut yield per palm due to the super cyclone and the palms under this damage category seldom produced any

Fig. 1 Rate of female flower in subsequent years

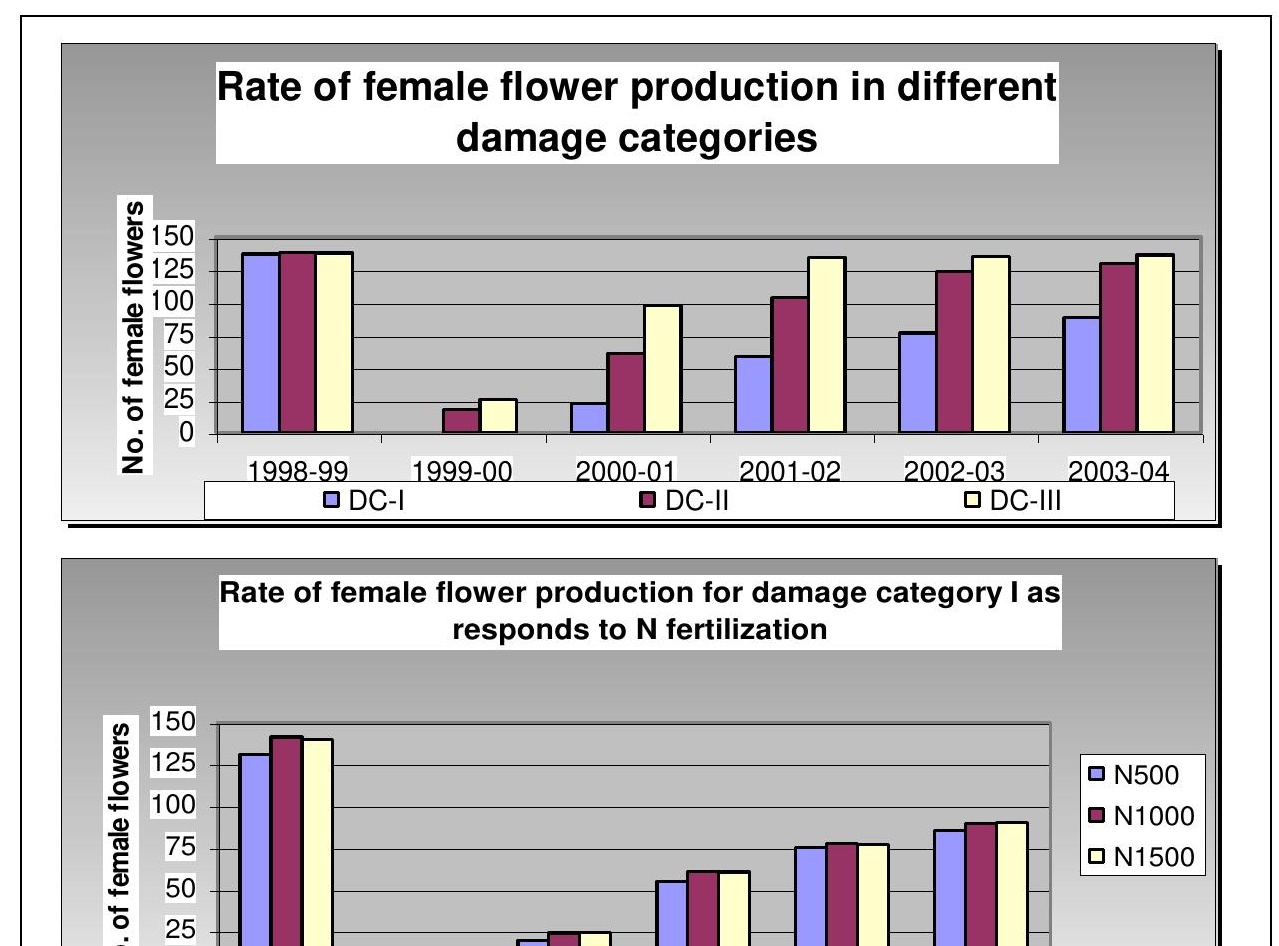


Cord 2007, 23 (2)

Fig 2. Annual nut yield in subsequent years
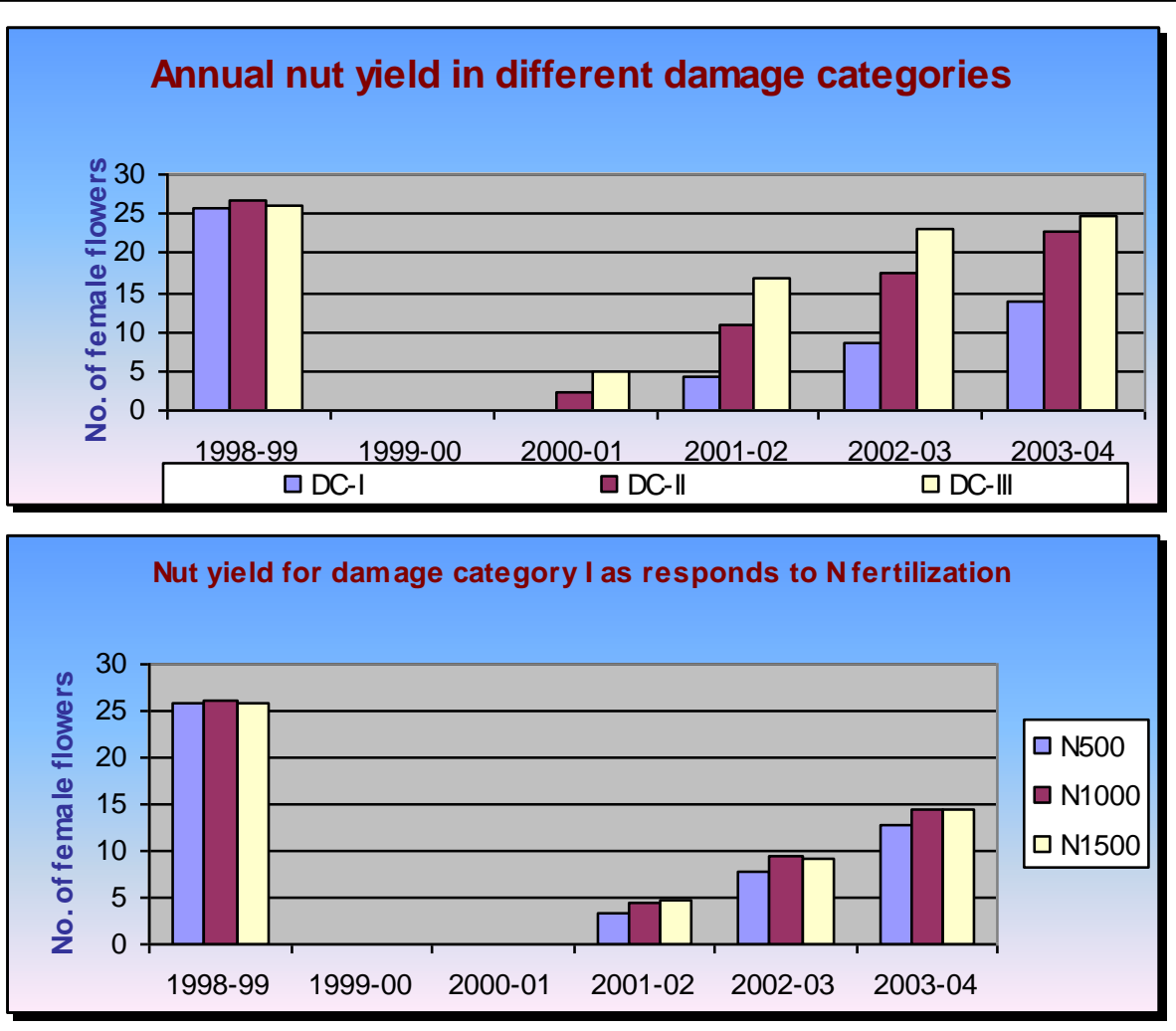
Cord 2007, 23 (2)

Table 6. Rate of female flower production (nos.) in successive years for damage category I

\begin{tabular}{|c|c|c|c|c|c|c|}
\hline \multirow[t]{2}{*}{ Treatment } & \multirow{2}{*}{$\begin{array}{c}\text { Pre-Cyclonic } \\
\text { period } \\
\text { 1998-99 } \\
\text { (Nov.-Oct.) }\end{array}$} & \multirow{2}{*}{$\begin{array}{c}\text { Cyclonic } \\
\text { period } \\
1999-00 \\
\text { (Nov.-June) }\end{array}$} & \multicolumn{4}{|c|}{ Post-cyclonic period } \\
\hline & & & $\begin{array}{c}2000-01 \\
\text { (July-June) }\end{array}$ & $\begin{array}{c}\text { 2001-02 } \\
\text { (July-June) }\end{array}$ & $\begin{array}{c}\text { 2002-03 } \\
\text { (July-June) }\end{array}$ & $\begin{array}{c}\text { 2003-04 } \\
\text { (July-June) }\end{array}$ \\
\hline \multicolumn{7}{|c|}{ Nitrogen $(g /$ plant $)$} \\
\hline $\mathrm{N}_{500}$ & 130.67 & In-sig. & 19.42 & 54.78 & 75.03 & 85.25 \\
\hline $\mathrm{N}_{1000}$ & 141.03 & In-sig. & 23.78 & 60.89 & 77.47 & 89.19 \\
\hline $\mathrm{N}_{1500}$ & 139.42 & In-sig. & 24.28 & 60.36 & 76.61 & 90.25 \\
\hline $\operatorname{SEm}( \pm)$ & 0.826 & --- & 0.334 & 0.353 & 0.496 & 0.533 \\
\hline C.D. (0.05) & 2.42 & --- & 0.98 & 1.03 & 1.45 & 1.56 \\
\hline \multicolumn{7}{|c|}{ Phosphorus ( $\mathrm{g} \mathrm{P}_{2} \mathrm{O}_{5} /$ plant $)$} \\
\hline $\mathrm{P}_{250}$ & 135.50 & In-sig. & 22.03 & 58.17 & 75.80 & 88.81 \\
\hline $\mathrm{P}_{500}$ & 137.75 & In-sig. & 22.89 & 59.17 & 77.20 & 88.39 \\
\hline $\mathrm{P}_{750}$ & 137.86 & In-sig. & 22.56 & 58.69 & 76.11 & 87.50 \\
\hline $\operatorname{SEm}( \pm)$ & 0.826 & --- & 0.334 & 0.353 & 0.496 & 0.533 \\
\hline C.D. (0.05) & NS & --- & NS & NS & NS & NS \\
\hline \multicolumn{7}{|c|}{ Potassium ( $\mathrm{g} \mathrm{K}_{2} \mathrm{O} /$ plant $)$} \\
\hline $\mathrm{K}_{750}$ & 137.53 & In-sig. & 22.97 & 59.22 & 76.89 & 88.47 \\
\hline $\mathrm{K}_{1250}$ & 137.94 & In-sig. & 22.50 & 58.50 & 76.58 & 88.83 \\
\hline $\mathrm{K}_{1750}$ & 135.64 & In-sig. & 22.00 & 58.31 & 75.64 & 87.39 \\
\hline $\operatorname{SEm}( \pm)$ & 0.826 & --- & 0.334 & 0.353 & 0.496 & 0.533 \\
\hline C.D. (0.05) & NS & --- & NS & NS & NS & NS \\
\hline
\end{tabular}




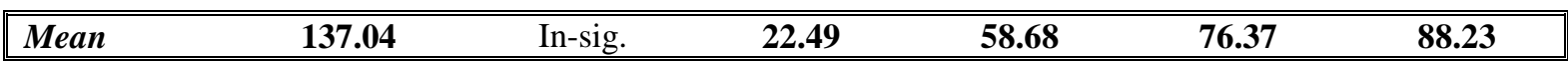

Table 7. Rate of female flower production (nos.) in successive years for damage category II

\begin{tabular}{|c|c|c|c|c|c|c|}
\hline \multirow[t]{2}{*}{ Treatment } & \multirow{2}{*}{$\begin{array}{c}\text { Pre- Cyclonic } \\
\text { period } \\
1998-99 \\
\text { (Nov.-Oct.) }\end{array}$} & \multirow{2}{*}{$\begin{array}{c}\text { Cyclonic } \\
\text { period } \\
1999-00 \\
\text { (Nov.-June) }\end{array}$} & \multicolumn{4}{|c|}{ Post-cyclonic period } \\
\hline & & & $\begin{array}{c}2000-01 \\
\text { (July-June) }\end{array}$ & $\begin{array}{c}2001-02 \\
\text { (July-June) }\end{array}$ & $\begin{array}{c}\text { 2002- } 03 \\
\text { (July-June) }\end{array}$ & $\begin{array}{c}2003-04 \\
\text { (July-June) }\end{array}$ \\
\hline \multicolumn{7}{|c|}{ Nitrogen $(\mathrm{g} /$ plant $)$} \\
\hline $\mathrm{N}_{500}$ & 132.06 & 16.19 & 56.11 & 100.14 & 120.03 & 127.39 \\
\hline $\mathrm{N}_{1000}$ & 142.36 & 18.92 & 63.56 & 105.86 & 124.75 & 130.75 \\
\hline $\mathrm{N}_{1500}$ & 140.22 & 18.56 & 62.69 & 104.83 & 126.24 & 131.93 \\
\hline $\operatorname{SEm}( \pm)$ & 0.892 & 0.200 & 0.531 & 0.459 & 0.992 & 0.532 \\
\hline C.D. (0.05) & 2.62 & 0.59 & 1.56 & 1.35 & 2.91 & 1.56 \\
\hline \multicolumn{7}{|c|}{ Phosphorus ( $\mathrm{g} \mathrm{P}_{2} \mathrm{O}_{5} /$ plant $)$} \\
\hline $\mathrm{P}_{250}$ & 136.64 & 17.53 & 59.86 & 102.92 & 122.14 & 130.21 \\
\hline $\mathrm{P}_{500}$ & 139.17 & 18.06 & 61.25 & 104.14 & 124.94 & 130.06 \\
\hline $\mathrm{P}_{750}$ & 138.83 & 18.08 & 61.25 & 103.78 & 123.94 & 129.81 \\
\hline $\operatorname{SEm}( \pm)$ & 0.892 & 0.200 & 0.531 & 0.459 & 0.992 & 0.532 \\
\hline C.D. (0.05) & NS & NS & NS & NS & NS & NS \\
\hline \multicolumn{7}{|c|}{ Potassium ( $\mathrm{g} \mathrm{K}_{2} \mathrm{O} /$ plant $)$} \\
\hline $\mathrm{K}_{750}$ & 138.11 & 18.06 & 61.03 & 103.69 & 123.11 & 130.42 \\
\hline $\mathrm{K}_{1250}$ & 139.53 & 17.97 & 60.72 & 104.08 & 123.84 & 130.36 \\
\hline $\mathrm{K}_{1750}$ & 137.00 & 17.64 & 60.61 & 103.06 & 124.07 & 129.29 \\
\hline $\operatorname{SEm}( \pm)$ & 0.892 & 0.200 & 0.531 & 0.459 & 0.992 & 0.532 \\
\hline C.D. (0.05) & NS & NS & NS & NS & NS & NS \\
\hline Mean & 138.21 & 17.89 & 60.79 & 103.61 & 123.67 & 130.02 \\
\hline
\end{tabular}

Table 8. Rate of female flower production (nos.) in successive years for damage category III

\begin{tabular}{|c|c|c|c|c|c|c|}
\hline \multirow[t]{2}{*}{ Treatment } & \multirow{2}{*}{$\begin{array}{c}\text { Pre-Cyclonic } \\
\text { period } \\
1998-99 \\
\text { (Nov.-Oct.) }\end{array}$} & \multirow{2}{*}{$\begin{array}{c}\text { Cyclonic } \\
\text { period } \\
1999-00 \\
\text { (Nov.-June) }\end{array}$} & \multicolumn{4}{|c|}{ Post-cyclonic period } \\
\hline & & & $\begin{array}{c}2000-01 \\
\text { (July-June) }\end{array}$ & $\begin{array}{c}2001-02 \\
\text { (July-June) }\end{array}$ & $\begin{array}{c}\text { 2002-03 } \\
\text { (July-June) }\end{array}$ & $\begin{array}{c}\text { 2003-04 } \\
\text { (July-June) }\end{array}$ \\
\hline \multicolumn{7}{|c|}{ Nitrogen $(g /$ plant $)$} \\
\hline $\mathrm{N}_{500}$ & 131.56 & 24.47 & 92.97 & 127.50 & 129.97 & 133.53 \\
\hline $\mathrm{N}_{1000}$ & 141.72 & 26.25 & 100.36 & 138.25 & 137.92 & 137.42 \\
\hline $\mathrm{N}_{1500}$ & 140.67 & 25.69 & 98.92 & 137.00 & 138.58 & 137.67 \\
\hline SEm ( \pm$)$ & 0.881 & 0.224 & 0.784 & 0.473 & 1.462 & 0.766 \\
\hline C.D. (0.05) & 2.58 & 0.66 & 2.30 & 1.39 & 4.29 & 2.25 \\
\hline \multicolumn{7}{|c|}{ Phosphorus ( $\left(\mathrm{P}_{2} \mathrm{O}_{5} /\right.$ plant $)$} \\
\hline $\mathrm{P}_{250}$ & 136.36 & 25.14 & 96.36 & 133.75 & 133.94 & 136.67 \\
\hline$P_{500}$ & 138.89 & 25.58 & 97.83 & 135.06 & 137.17 & 136.89 \\
\hline $\mathrm{P}_{750}$ & 138.69 & 25.69 & 98.06 & 133.94 & 135.36 & 135.06 \\
\hline $\operatorname{SEm}( \pm)$ & 0.881 & 0.224 & 0.784 & 0.473 & 1.462 & 0.766 \\
\hline C.D. (0.05) & NS & NS & NS & NS & NS & NS \\
\hline \multicolumn{7}{|c|}{ Potassium ( $\mathrm{g} \mathrm{K}_{2} \mathrm{O} /$ plant $)$} \\
\hline $\mathrm{K}_{750}$ & 138.00 & 25.44 & 98.08 & 134.44 & 134.47 & 137.28 \\
\hline $\mathrm{K}_{1250}$ & 138.83 & 25.81 & 97.25 & 134.42 & 138.03 & 135.75 \\
\hline $\mathrm{K}_{1750}$ & 137.11 & 25.17 & 96.92 & 133.89 & 133.97 & 135.58 \\
\hline SEm & 0.881 & 0.224 & 0.784 & 0.473 & 1.462 & 0.766 \\
\hline C.D. (0.05) & NS & NS & NS & NS & NS & NS \\
\hline Mean & 137.98 & 25.47 & 97.42 & 134.25 & 135.49 & 136.20 \\
\hline
\end{tabular}


Table 9. Annual nut production (per palm) in successive years for damage category I

\begin{tabular}{|c|c|c|c|c|c|c|}
\hline \multirow[t]{2}{*}{ Treatment } & \multirow{2}{*}{$\begin{array}{c}\text { Pre- Cyclonic } \\
\text { period } \\
\text { 1998-99 } \\
\text { (Nov.-Oct.) }\end{array}$} & \multirow{2}{*}{$\begin{array}{c}\text { Cyclonic } \\
\text { period } \\
1999-00 \\
\text { (Nov.-June) }\end{array}$} & \multicolumn{4}{|c|}{ Post-cyclonic period } \\
\hline & & & $\begin{array}{c}2000-01 \\
\text { (July-June) }\end{array}$ & $\begin{array}{c}2001-02 \\
\text { (July-June) }\end{array}$ & $\begin{array}{c}\text { 2002-03 } \\
\text { (July-June) }\end{array}$ & $\begin{array}{c}\text { 2003-04 } \\
\text { (July-June) }\end{array}$ \\
\hline \multicolumn{7}{|c|}{ Nitrogen $(\mathrm{g} /$ plant $)$} \\
\hline $\mathrm{N}_{500}$ & 25.72 & Nil & In-sig. & 3.36 & 7.75 & 12.69 \\
\hline $\mathrm{N}_{1000}$ & 26.06 & Nil & In-sig. & 4.44 & 9.42 & 14.58 \\
\hline $\mathrm{N}_{1500}$ & 25.75 & Nil & In-sig. & 4.78 & 9.03 & 14.36 \\
\hline SEm $( \pm)$ & 0.404 & --- & --- & 0.138 & 0.234 & 0.171 \\
\hline C.D. (0.05) & NS & --- & --- & 0.40 & 0.68 & 0.51 \\
\hline \multicolumn{7}{|c|}{ Phosphorus ( $\mathrm{g}_{2} \mathrm{O}_{5} /$ plant $)$} \\
\hline $\mathrm{P}_{250}$ & 25.86 & Nil & In-sig. & 4.11 & 8.78 & 13.69 \\
\hline $\mathrm{P}_{500}$ & 25.31 & Nil & In-sig. & 4.25 & 8.72 & 14.14 \\
\hline $\mathrm{P}_{750}$ & 26.36 & Nil & In-sig. & 4.22 & 8.69 & 13.81 \\
\hline SEm $( \pm)$ & 0.404 & --- & --- & 0.138 & 0.234 & 0.171 \\
\hline C.D. (0.05) & NS & --- & --- & NS & NS & NS \\
\hline \multicolumn{7}{|c|}{ Potassium ( $\mathrm{g} \mathrm{K}_{2} \mathrm{O} /$ plant $)$} \\
\hline $\mathrm{K}_{750}$ & 25.36 & Nil & In-sig. & 4.28 & 8.47 & 13.61 \\
\hline $\mathrm{K}_{1250}$ & 25.75 & Nil & In-sig. & 4.22 & 8.94 & 14.03 \\
\hline $\mathrm{K}_{1750}$ & 26.42 & Nil & In-sig. & 4.08 & 8.78 & 14.00 \\
\hline $\operatorname{SEm}( \pm)$ & 0.404 & --- & --- & 0.138 & 0.234 & 0.171 \\
\hline C.D. (0.05) & NS & --- & --- & NS & NS & NS \\
\hline Mean & 25.84 & --- & In-sig. & 4.19 & 8.73 & 13.88 \\
\hline
\end{tabular}

Table 10. Annual nut production (per palm) in successive years for damage category II

\begin{tabular}{|c|c|c|c|c|c|c|}
\hline \multirow[t]{2}{*}{ Treatment } & \multirow{2}{*}{$\begin{array}{c}\text { Pre- Cyclonic } \\
\text { period } \\
\text { 1998-99 } \\
\text { (Nov.-Oct.) }\end{array}$} & \multirow{2}{*}{$\begin{array}{c}\text { Cyclonic } \\
\text { period } \\
1999-00 \\
\text { (Nov.-June) }\end{array}$} & \multicolumn{4}{|c|}{ Post-cyclonic period } \\
\hline & & & $\begin{array}{c}2000-01 \\
\text { (July-June) }\end{array}$ & $\begin{array}{c}\text { 2001-02 } \\
\text { (July-June) }\end{array}$ & $\begin{array}{c}\text { 2002-03 } \\
\text { (July-June) }\end{array}$ & $\begin{array}{c}\text { 2003-04 } \\
\text { (July-June) }\end{array}$ \\
\hline \multicolumn{7}{|c|}{ Nitrogen $(g /$ plant $)$} \\
\hline $\mathrm{N}_{500}$ & 26.33 & In-sig. & 2.22 & 9.47 & 16.31 & 22.17 \\
\hline $\mathrm{N}_{1000}$ & 26.94 & In-sig. & 2.53 & 11.58 & 18.25 & 22.94 \\
\hline $\mathrm{N}_{1500}$ & 26.42 & In-sig. & 2.64 & 11.69 & 17.75 & 22.72 \\
\hline $\operatorname{SEm}( \pm)$ & 0.350 & --- & 0.085 & 0.222 & 0.246 & 0.303 \\
\hline C.D. (0.05) & NS & --- & 0.25 & 0.65 & 0.72 & NS \\
\hline \multicolumn{7}{|c|}{ Phosphorus ( $\mathrm{g} \mathrm{P}_{2} \mathrm{O}_{5} /$ plant $)$} \\
\hline $\mathrm{P}_{250}$ & 26.69 & In-sig. & 2.39 & 10.89 & 17.33 & 22.72 \\
\hline $\mathrm{P}_{500}$ & 26.08 & In-sig. & 2.58 & 10.78 & 17.64 & 22.69 \\
\hline $\mathrm{P}_{750}$ & 26.92 & In-sig. & 2.42 & 11.08 & 17.33 & 22.42 \\
\hline $\operatorname{SEm}( \pm)$ & 0.350 & --- & 0.085 & 0.222 & 0.246 & 0.303 \\
\hline C.D. (0.05) & NS & --- & NS & NS & NS & NS \\
\hline \multicolumn{7}{|c|}{ Potassium ( $\mathrm{g} \mathrm{K}_{2} \mathrm{O} /$ plant $)$} \\
\hline $\mathrm{K}_{750}$ & 26.14 & In-sig. & 2.28 & 10.45 & 17.08 & 22.31 \\
\hline $\mathrm{K}_{1250}$ & 26.53 & In-sig. & 2.56 & 11.17 & 17.67 & 23.06 \\
\hline $\mathrm{K}_{1750}$ & 27.03 & In-sig. & 2.56 & 11.13 & 17.56 & 22.47 \\
\hline $\operatorname{SEm}( \pm)$ & 0.350 & --- & 0.085 & 0.222 & 0.246 & 0.303 \\
\hline C.D. (0.05) & NS & --- & 0.25 & 0.65 & NS & NS \\
\hline Mean & 26.56 & In-sig. & 2.46 & 10.92 & 17.44 & 22.61 \\
\hline
\end{tabular}

Table 11. Annual nut production (per palm) in successive years for damage category III 


\begin{tabular}{|c|c|c|c|c|c|c|}
\hline \multirow[t]{2}{*}{ Treatment } & \multirow{2}{*}{$\begin{array}{c}\text { Pre- Cyclonic } \\
\text { period } \\
\text { 1998-99 } \\
\text { (Nov.-Oct.) }\end{array}$} & \multirow{2}{*}{$\begin{array}{c}\text { Cyclonic } \\
\text { period } \\
\text { 1999-00 } \\
\text { (Nov.-June) }\end{array}$} & \multicolumn{4}{|c|}{ Post-cyclonic period } \\
\hline & & & $\begin{array}{c}\text { 2000-01 } \\
\text { (July-June) }\end{array}$ & $\begin{array}{c}\text { 2001-02 } \\
\text { (July-June) }\end{array}$ & $\begin{array}{c}\text { 2002-03 } \\
\text { (July-June) }\end{array}$ & $\begin{array}{c}\text { 2003-04 } \\
\text { (July-June) }\end{array}$ \\
\hline \multicolumn{7}{|c|}{ Nitrogen ( $g /$ plant $)$} \\
\hline $\mathrm{N}_{500}$ & 25.83 & In-sig. & 4.69 & 15.56 & 23.61 & 24.15 \\
\hline $\mathrm{N}_{1000}$ & 26.50 & In-sig. & 5.14 & 17.44 & 23.44 & 25.11 \\
\hline $\mathrm{N}_{1500}$ & 26.19 & In-sig. & 5.11 & 17.17 & 22.67 & 24.89 \\
\hline $\operatorname{SEm}( \pm)$ & 0.367 & --- & 0.118 & 0.286 & 0.385 & 0.497 \\
\hline C.D. (0.05) & NS & --- & 0.35 & 0.84 & NS & NS \\
\hline \multicolumn{7}{|c|}{ Phosphorus ( $\mathrm{g} \mathrm{P}_{2} \mathrm{O}_{5} /$ plant $)$} \\
\hline $\mathrm{P}_{250}$ & 26.19 & In-sig. & 5.16 & 16.69 & 23.06 & 24.81 \\
\hline $\mathrm{P}_{500}$ & 25.69 & In-sig. & 4.96 & 17.06 & 22.89 & 24.32 \\
\hline $\mathrm{P}_{750}$ & 26.64 & In-sig. & 4.83 & 16.42 & 23.78 & 25.03 \\
\hline $\operatorname{SEm}( \pm)$ & 0.367 & --- & 0.118 & 0.286 & 0.385 & 0.497 \\
\hline C.D. (0.05) & NS & --- & NS & NS & NS & NS \\
\hline \multicolumn{7}{|c|}{ Potassium ( $\mathrm{g} \mathrm{K} \mathrm{K}_{2} \mathrm{O} /$ plant $)$} \\
\hline $\mathrm{K}_{750}$ & 25.75 & In-sig. & 4.86 & 16.25 & 22.78 & 24.81 \\
\hline $\mathrm{K}_{1250}$ & 26.14 & In-sig. & 5.06 & 16.94 & 23.17 & 24.64 \\
\hline $\mathrm{K}_{1750}$ & 26.64 & In-sig. & 5.03 & 16.97 & 23.78 & 24.71 \\
\hline $\operatorname{SEm}( \pm)$ & 0.367 & --- & 0.118 & 0.286 & 0.385 & 0.497 \\
\hline C.D. (0.05) & NS & --- & NS & NS & NS & NS \\
\hline Mean & 26.18 & In-sig. & 4.98 & 16.72 & 23.24 & 24.72 \\
\hline
\end{tabular}

nuts during the initial eight months of cyclonic disturbances. However, the palms started bearing nuts in the leaf axils from 2000-01 with 4.98 nuts, which then increased smoothly to 16.72 , 23.24, and 24.72 during 2001-02, 2002-03 and 2003-04, respectively.

A critical analysis of the data recorded under varying levels of nitrogen revealed that the average nut yield per palm at $\mathrm{N}_{500}$ was 4.69 and 15.56 during 2000-01 and 2001-02, respectively, then significantly increased to 5.14 and 17.44 with the application of $1000 \mathrm{~g}$ nitrogen per palm per year. It was also observed that further increase in the nitrogen dose beyond $1000 \mathrm{~g}$ per palm per year was not of any practical utility as at higher level the results obtained were at par with those obtained at $\mathrm{N}_{1000}$ in terms of the annual nut yield per palm.

\section{Discussion}

\section{Rate of production of inflorescences}

From the results recorded in the study, it is evident that the difference in the nitrogen doses produced considerable variation with respect to the production of inflorescences per palm under different categories of damage. An overall look of the data revealed that the palms under damage category I have rarely produced any inflorescences during the first 8 months of cyclone damage, whereas, the palms in other categories of damage took about 4-5 months to start producing new inflorescences. The results of the present study were more or less similar to the findings of Dash et al., (2002). The highest number of inflorescences was found produced in the palms fertilized with $1000 \mathrm{~g}$ nitrogen per palm during 2001-02 to 2003-04 under damage category I, while application of $1500 \mathrm{~g}$ nitrogen per palm resulted in the production of more number of inflorescences during 2000-01. The higher doses of nitrogen (1000 and $1500 \mathrm{~g}$ ) produced at par results and both were superior to that recorded under $\mathrm{N}_{500}$ in this category of damage except in 2003-04, where neither of the levels of nitrogen had any significant effect in respect of this character. In the same way, the production of inflorescences per palm was at higher side in the palms fertilized with 1000 and $1500 \mathrm{~g}$ nitrogen per palm during 1999-00 to 2001-02 under damage category II and III. However, the results obtained in these two treatments were at par and both were significantly superior to that recorded in the 
palms fertilized with $500 \mathrm{~g}$ nitrogen per palm per year during these periods. At the later stages of the experiment, no marked variation among the three doses of nitrogen was observed with respect to production of inflorescences per palm under these categories of damages. Thus, the superiority of the $1000 \mathrm{~g}$ nitrogen over the higher $(1500 \mathrm{~g})$ as well as lower dose $(500 \mathrm{~g})$ is imperative as far as the production of inflorescences is concerned. This result was in agreement with the result obtained by Nelliat (1974) on coconut.

Palms fertilized with different doses of phosphorus and potassium did not show any significant variation as regards to the production of inflorescences per palm in either of the damage category during the entire period of study.

\section{Rate of female flower production}

The female flower production has nearly become normal after 3 and 4 years of cyclone in damage category III and II, correspondingly. But, the palms with a more severe damage were yet to restore the bearing potentiality by the time the study period ended. It is the number of female flowers in the palm that influences the yield. Nitrogen showed significant influence on this character in this study. There were progressive and significant improvements in the production of female flowers per palm over the years with the application of enhanced dose of nitrogen i.e., $1000 \mathrm{~g}$ per palm per year. This trend was consistently seen in all the palms under all categories of damage. However, the response to application of the upper dose, $1500 \mathrm{~g}$ nitrogen per palm per year, was non-significant when compared to that observed in $\mathrm{N}_{1000}$. The beneficial effects of nitrogenous fertilizers on female flower production in coconut had also been reported by Salgado (1946 a, b), Smith (1969), Nelliat (1974), Nelliat et al. (1978) and Thampan (1982). The variations in the production of female flowers per palm due to different levels of phosphorus and potassium were not significant during the entire period of study. Salgado (1946 a, b) working on effect of fertilization on coconut production also opined that potassium has a very little effect on this character.

\section{Annual nut yield per palm}

There was a significant reduction in the nut production per palm after the cyclonic turbulence. The early periods of the cyclone damage were marked by the absence any nut in the palms under all the three categories of damage. The recovery process started only after $1 \frac{1}{2}$ years in the palms affected with II and III category of damages whilst the palms with most severe damage took about one more year to resume the nut production.

The application of different nutrients produced remarkable and useful responses with regard to the nut yield per palm per year. Nitrogen application up to $1000 \mathrm{~g}$ per palm per year resulted in significant improvement in annual nut yield during the period of investigation in the damage category I. The significant effects of using $1000 \mathrm{~g}$ nitrogen were observed during the period 2000-01 to 2002-03 in the palms under damage category II, also in 2000-01 to 2001-02 for palms under damage category III. On the contrary, the maximum dose of nitrogen (1500 g per palm per year) shaped results at par with the $1000 \mathrm{~g}$ nitrogen in terms of the nut yield per palm. Anon, 1956; Prudente and Mendoza, 1979 and Gopi et al., 1982, have also reported similar results of application of nitrogen for yield improvement in coconut. Studies conducted by Nair and Sreedharan (1982) have shown that higher levels of application of nitrogen increase the yield in oil palm. The results of a series of experiments conducted by Rosenquist (1962) on the Rengam soil indicated the need for higher rate of nitrogen application for a response of that element to yield. The present study revealed that the optimum dose of nitrogen is $1000 \mathrm{~g}$ per palm per year to cause the full expression of the genetic potential of the palms in terms of nut yield. Beyond this level no significant increase in productivity was obtained in this experiment.

Different levels of phosphorus did not cause any obvious response as regards to nut 
yield per palm per year in any of the damage categories. This shows the ineffectiveness of different levels of phosphorus tested, throughout the experiment.

It has become clear that nitrogen is the most decisive element for recovery of the palms after the cyclone. However, the significance of other two elements tested in this study (phosphorus and potassium) must not be disregarded as in some cases they stimulate the growth and production in the palms either alone or in combination with nitrogen. The palms under damage category I continued to be very poor in yield even after $4 \frac{1}{2}$ years of cyclone damage raising questions about the feasibility of their recovery with fertilization, while, the palms under damage category II and III, more or less behaved normally by the end of the experimental period.

\section{Acknowledgement}

The authors are highly thankful to Dr. H. Hameed Khan, Ex-Project Co-ordinator (AICRP, Palms), and Dr. V. Niral; Senior Scientist, CPCRI, Kasaragod for their valuable suggestions.

\section{Bibliography}

Anonymous (1956). Annual Report of the Coconut Research Institute, Ceylon. Ceylon Coconut Quarterly, 7 : 4-67.

Dash, D.K., Ray, D.P. and Khan, H.H. (2002). Extent of damage to coconut palms caused by super cyclone in Orissa and pattern of their recovery. CORD (Coconut Research and Development), XVIII (1) : 29-40.

Gopi, C.S., Jose, A.I. and Koshy, E.P. (1982). Standardization of leaf position for foliar diagnosis of nitrogen in coconut. Proceedings of PLACROSYM V. (Bavappa, K.V.A., ed.), pp. 468-473.

Jackson, M.L. (1973). Soil Chemical Analysis. Prentice-Hall of India Pvt. Ltd., New Delhi.
Nair, M.A. and Sreedharan, C. (1982). Nutritional requirement of oil palm. Journal of Plantation Crops, 10 (1) : 4552.

Nelliat, E.V. (1974). NPK nutrition of coconut palm- A review. Journal of Plantation crops, 1 (supplement) : 70-80.

Nelliat, E.V., Nair, R.V. and Thomas Varghese, P. (1978). Response of high yielding coconut genotypes to fertilizer levels under rainfed conditions. Proceedings of the first Annual Symposium on Plantation Crops (Nelliat, E.V., ed.), pp. 87-100.

Patel, J.S. (1938). The Coconut-A Monograph. Govt. Press, Madras

Piper, C.S. (1950). Soil and Plant Analysis. Hassel Press, Adelaide (Australia).

Prudente, R.L. and Mendoza, A.M.R. (1979). The effect of NPK fertilizers on coconut from transplanting to full bearing. Potash Review, 27: 88.

Rosenquist, A.E. (1962). Fertilizer experiments on oil palms in Malay, Part I-Yield data. J.W.Afr. Inst. Oil Palm Research, 3 : 921.

Salgado, M.L.M. (1946 a). New developments in coconut manuring. Coconut Research Scheme, Leaflet No. 8.

Salgado, M.L.M. (1946 b). Notes on manuring of coconut palms. Coconut Research Scheme, Leaflet No. 12.

Smith, R.W. (1969). Fertilizer responses by coconut in two contrasting Jamaican soils. Experimental Agriculture, 5 : 133-145.

Subbiah, B.V. and Asija, G.L. (1956). A rapid method for the estimation of available nitrogen in soils. Current Science, 25 : 259-260. 
Cord 2007, 23 (2)

Thampan, P.K. (1982). Handbook on Coconut

Kolkatta, pp. 81-157. Palm. Oxford and IBH Publishing Co. 